\title{
COMPARISON OF THE DIURETIC ACTION OF SODIUM DEHYDROCHOLATE AND MERCUPURIN IN MAN ${ }^{1}$
}

\author{
By WALTER MODELL AND HARRY GOLD \\ (From the Department of Pharmacology of Cornell University Medical College and the \\ Cardiac Services of the Beth Israel Hospital and Hospital for \\ Joint Diseases, New York City)
}

(Received for publication October 25, 1944)

This paper deals with the results of experiments planned to investigate the diuretic action of sodium dehydrocholate (decholin sodium ${ }^{2}$ ) in cardiac patients with congestive heart failure and to compare its action with that of the organic mercurial, mercupurin. While there are several reports in the literature suggesting that decholin sodium has diuretic properties, the methods employed for its study heretofore leave its efficacy open to question. In the present study, the observations were made on ambulatory patients, and the diuresis was determined by change in weight in a manner similar to that described in a previous investigation (1). In this method, the patient loses weight as the result of the dose of the diuretic agent, and regains it by the time of the next injection. It is therefore possible to repeat the same dose, under essentially similar conditions of edema in the same patient, as many times as is necessary to secure a reliable average response to a given dose.

Neubauer (2) appears to have been the first to direct attention to the possible use of decholin sodium as a diuretic agent. $\mathrm{He}$ observed that this action in man is feeble and inconstant. Several reports have since appeared describing the diuretic activity of decholin sodium. It did not seem profitable to present a detailed review of all of them, but we may refer to a number of representative papers, sufficient to indicate the statements concerning the diuretic action of decholin sodium which one is likely to encounter. From the scientific standpoint, the literature on this subject is not satisfactory. Many of the reports are based on routine experiences rather than on the results of experiments so designed as to eliminate common sources of error and to

1 This study was supported in part by a grant from Riedel-de Haen, Inc.

2 Riedel-de Haen, Inc. supply data suitable for objective analysis. While there is general agreement that decholin sodium exerts a diuretic action, views differ concerning its extent and regularity. Some found that it rarely fails to produce diuresis (3), others that it fails in 40 per cent of the cases (4). Most reports found it less effective than the organic mecurials (5), others as effective as, or often even more effective than the organic mercurials (6). Certain workers (7) noted that while the daily increase in urine is slight or inconstant, especially in those without edema, the drug regularly increases the urine in the first 2 hours, an effect which subsides in 3 to 5 hours. The view was expressed in some of the earlier papers that decholin sodium prolongs or enhances the diuretic effect of the organic mercurials. It has been stated (8), but without sufficient evidence, that the 2 gram dose of decholin sodium produced the effect of the $1 \mathrm{ml}$. rather than of the $2 \mathrm{ml}$. dose of salyrgan, and that the combination of the two agents sometimes caused additive, sometimes potentiative effects. The synergism was stressed in a more recent report (9) but again without evidence, since the paper shows insufficient controls with comparable doses of the organic mercurial alone. The dose employed in most of the reports was 2 grams of decholin sodium given intravenously as $10 \mathrm{ml}$. of a 20 per cent solution, although doses of 4 grams have also been used (3). It was repeated daily or every other day without apparent poisoning. Most reports noted the bitter taste after the injection. Some observed slowing of the heart rate and temporary fall of the blood pressure by as much as $30 \mathrm{~mm}$. $\mathrm{Hg}$ (4), while others observed no effect on either. An occasional rise of the temperature and, after repeated daily injections, a mild diarrhea have been reported (10). It is stated that the drug exerts a diuretic action in normal subjects and in 
patients with edema in association with cardiac, renal, or hepatic disease, the effect being smallest in the normal and greatest in those with cardiac edema (11). Although the effect of decholin sodium is less than that of the organic mercurials, it has been suggested, but without sufficient proof, that it might be useful in cardiac edema not only when other diuretics cannot be used, but when others fail (11).

Little is known concerning the mechanism of the diuretic action of decholin sodium. Observations have been presented (12) in support of the belief that the effect is mediated through a primary action on the mechanism of water storage in the liver. Certain authors (13) noted that intravenous doses of decholin sodium exert a nephrotoxic action in cats and dogs resulting in tubular degeneration. Another (14) was unable to confirm it in cats. The belief has been expressed (15) that both renal and hepatic action are responsible for the diuresis.

\section{EXPERIMENTAL}

The observations of the present study were made in a group of 32 ambulatory cardiac patients selected from among 1500 patients in attendance in the cardiac clinics. The characteristics of those that received decholin are summarized in Table I. They all had advanced organic heart disease and far advanced failure with congestion. The more common etiological varieties of heart diseases are represented. All had fairly marked enlargement of the liver due to chronic passive congestion. These patients had been in attendance in our clinics for periods of several years. They were under continuous treatment with digitalis. The heart failure had reached a stage in which digitalis in full dosage was no longer sufficient to maintain the patients in reasonable comfort and free of edema. They were able to remain up and about and to carry on moderate activity only through the aid of mercurial diuretics which had been used in these cases for periods up to 2 years.

The effect of the drug was studied by means of the following: (1) amount of diuresis, (2) size of liver, (3) heart rate, (4) blood pressure, (5) urinalysis, (6) blood N.P.N., (7) subjective symptoms and reactions. The patient was weighed just before the injection, and again, 15 hours later. The loss in weight was taken to represent the diuretic effect. This procedure was repeated every week. For comparison of different drugs or doses, each was alternated with the other for several weeks. Changes in liver size were determined weekly by measuring the perpendicular distance between the tip of the xiphoid process and the liver edge. The heart rate and blood pressure were taken during each visit. The urine was examined for albumin and formed ele-
TABLE I

Characteristics of patients used in study

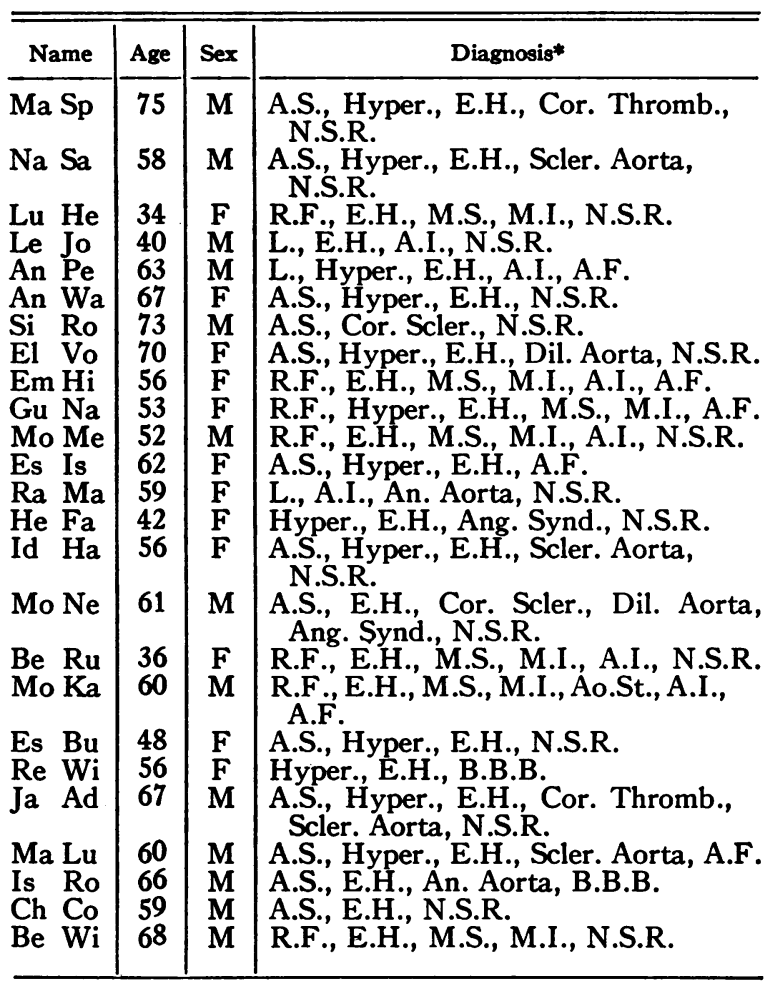

* According to "Nomenclature and Criteria for Diagnosis of Diseases of the Heart" of the New York Heart Association (1942).

A.S. (Arteriosclerosis); R.F. (Rheumatic Fever); L. (Lues); Hyper. (Hypertension); E.H. (Enlarged Heart); Cor. Scler. (Coronary Sclerosis); Cor. Thromb. (Coronary Thrombosis); Scler. Aorta (Sclerosis of the Aorta); Dil. Aorta (Dilatation of the Aorta); An. Aorta (Aneurysm of the Aorta); M.S. (Mitral Stenosis); M.I. (Mitral Insuffciency); Ao.St.(Aortic Stenosis); A.I. (Aortic Insufficiency) N.S.R. (Normal Sinus Rhythm); A.F. (Auricular Fibrillation); B.B.B. (Bundle Branch Block); Ang. Synd. (Anginal Syndrome).

ments, and the blood N.P.N. was determined at intervals of 2 weeks. The decholin sodium was used in 20 per cent solution in doses of $10 \mathrm{ml}$. or 2.0 grams. It was administered intravenously, taking 2 to 3 minutes for the injection. Most patients received 4 such doses, either alone, or in combination with mercupurin. When the two drugs were given together, they were mixed in the same syringe. The mercupurin was also injected intravenously.

\section{RESULTS}

There were, in all, 234 intravenous injections of mercupurin and 98 of decholin sodium. The results of the experiments which were satisfactorily completed have been assembled in Table II. In view of the fact that the patient was weighed 
TABLE II

Comparison of decholin and mercupurin under various conditions

\begin{tabular}{|c|c|c|c|c|c|c|}
\hline \multirow{2}{*}{ Drug } & \multirow{2}{*}{ Dose } & \multirow{2}{*}{$\begin{array}{c}\text { No. } \\
\text { of } \\
\text { tests }\end{array}$} & \multirow{2}{*}{$\begin{array}{c}\text { No. } \\
\text { of } \\
\text { pa- } \\
\text { tients }\end{array}$} & \multicolumn{3}{|c|}{ Wt. loss (lbs.) } \\
\hline & & & & $\begin{array}{c}\text { Aver- } \\
\text { age }\end{array}$ & S.E. & Range \\
\hline \multicolumn{7}{|c|}{$-A-$} \\
\hline $\mathbf{0}$ & $\mathbf{0}$ & 13 & 10 & 0.4 & \pm 0.2 & $\begin{array}{c}-1.25 \text { to } \\
+1.0^{*}\end{array}$ \\
\hline \multicolumn{7}{|c|}{$-\mathbf{B}-$} \\
\hline $\begin{array}{l}\text { Mercupurin } \\
\text { Decholin } \\
\text { Mixture } \\
\text { Mercupurin } \\
\text { Decholin }\end{array}$ & $\begin{array}{l}1 \text { or } 2 \mathrm{ml} \text {. } \\
2 \text { grams } \\
1 \text { or } 2 \mathrm{ml} \text {. } \\
2 \text { grams }\end{array}$ & $\begin{array}{l}93 \\
55 \\
38\end{array}$ & $\begin{array}{l}22 \\
22 \\
21\end{array}$ & $\begin{array}{l}4.9 \\
1.5 \\
6.2\end{array}$ & $\begin{array}{l} \pm 0.39 \\
\pm 0.18 \\
\pm 0.44\end{array}$ & $\begin{array}{l}0.5 \text { to } 15.5 \\
0 \text { to } 4.5 \\
0 \text { to } 13.0\end{array}$ \\
\hline \multicolumn{7}{|c|}{$-\mathrm{c}-$} \\
\hline $\begin{array}{l}\text { Mercupurin } \\
\text { Mercupurin } \\
\text { Mercupurin } \\
\text { Decholin }\end{array}$ & $\begin{array}{l}1 \mathrm{ml} . \\
2 \mathrm{ml} . \\
2 \mathrm{nd} \mathrm{ml} . \\
2 \text { grams }\end{array}$ & $\begin{array}{l}31 \\
31 \\
31 \\
16\end{array}$ & $\begin{array}{l}6 \\
6 \\
6 \\
6\end{array}$ & $\begin{array}{l}5.1 \\
7.0 \\
1.9 \dagger \\
1.7\end{array}$ & $\begin{array}{l} \pm 0.30 \\
\pm 0.28 \\
\pm 0.36\end{array}$ & $\begin{array}{l}3.6 \text { to } 6.8 \\
4.3 \text { to } 8.1 \\
0 \text { to } 4.5\end{array}$ \\
\hline \multicolumn{7}{|c|}{$-D-$} \\
\hline $\begin{array}{l}\text { Mercupurin } \\
\text { Decholin } \\
\text { Mixture } \\
\text { Mercupurin } \\
\text { Decholin }\end{array}$ & $\begin{array}{l}1 \text { ml. } \\
2 \text { grams } \\
1 \text { ml. } \\
2 \text { grams }\end{array}$ & $\begin{array}{l}57 \\
33 \\
24\end{array}$ & $\begin{array}{l}14 \\
14 \\
13\end{array}$ & $\begin{array}{l}4.9 \\
1.8 \\
6.3\end{array}$ & $\begin{array}{l} \pm 0.44 \\
\pm 0.23 \\
\pm 0.38\end{array}$ & $\begin{array}{l}1.0 \text { to } 9.3 \\
0 \text { to } 4.5 \\
3.0 \text { to } 10.3\end{array}$ \\
\hline \multicolumn{7}{|c|}{$-\mathbf{E}-$} \\
\hline $\begin{array}{l}\text { Mercupurin } \\
\text { Decholin } \\
\text { Mixture } \\
\text { Mercupurin } \\
\text { Decholin }\end{array}$ & $\begin{array}{l}2 \text { ml. } \\
2 \text { grams } \\
2 \text { ml. } \\
2 \text { grams }\end{array}$ & $\begin{array}{l}36 \\
22 \\
14\end{array}$ & $\begin{array}{l}9 \\
8 \\
8\end{array}$ & $\begin{array}{l}5.1 \\
0.9 \\
5.9\end{array}$ & $\begin{array}{l} \pm 0.66 \\
\pm 0.22 \\
\pm 1.02\end{array}$ & $\begin{array}{l}0.5 \text { to } 15.5 \\
0 \text { to } 4.0 \\
0 \text { to } 13.0\end{array}$ \\
\hline
\end{tabular}

* Control cases are only instances of gain in weight. † Obtained by subtracting the $5.1 \mathrm{ml}$. from the $7.0 \mathrm{ml}$. S.E. (Standard Error).

and received the injection in the evening, and the loss of weight was determined the following morning, there was the possibility that in this period the effect of rest in bed, bowel movement, and food intake might result in a change in weight without drug. This was tested in 13 trials (Group A). The results show that while some gained and others lost weight, the net result was an average 0.4 pound loss of weight in the 15hour period without drug, an amount which is close to the limit of accuracy of the scale for weighing the patients and outside of the range of the vast majority of losses of weight occurring after the diuretic agents. Since the data were not sufficient to determine the precision of this factor, the ratios in the tables were calculated on the basis of the actual changes in weight following the use of the diuretic agents.

Mercupurin showed a failure of diuretic response in 3 per cent of 134 tests and decholin sodium failed in 19.6 per cent of 56 tests.

After the intravenous injection of 2 grams of decholin sodium, patients with cardiac edema developed a diuresis and lost an average of 1.5 pounds. This was about 30 per cent of the effect of 1 or $2 \mathrm{ml}$. of mercupurin in the same group of patients (Group B). When the decholin sodium and mercupurin were injected together, the diuresis was greater than with either alone and the increase represented essentially a summation of the two actions.

In one group of 6 patients (Group C) who were tested by both a $1 \mathrm{ml}$. and a $2 \mathrm{ml}$. dose of mercupurin, it was found that the 2 gram dose of decholin sodium produced only about 33 per cent of the effect of the first $\mathrm{ml}$. of mercupurin but its effect was nearly equal to that of the second $\mathrm{ml}$. of mercupurin. Its effect was, therefore, nearly equal to the extra effect of doubling the dose of mercupurin in this dosage range.

Among the patients receiving mercupurin, there were those who were more susceptible (Group D), requiring only the $1 \mathrm{ml}$. dose, and those who were more tolerant (Group E), requiring the 2 $\mathrm{ml}$. dose for the production of enough diuresis to control symptoms effectively. This difference in tolerance extended also to decholin sodium since the $\mathbf{2}$ gram dose produced only one-half as much diuresis in those resistant as in those more susceptible to mercupurin. These groups also show that the combined use of decholin sodium and mercupurin produces substantially summative diuresis.

The foregoing relationships have been summarized in Table III.

The size of the liver was uninfluenced by the manner of the treatment in these cases. The average size in 14 patients (17 tests) was $9 \mathrm{~cm}$. before and $9.5 \mathrm{~cm}$. after the dose in the case of the mercupurin, and in 16 patients (19 tests), it was $11.4 \mathrm{~cm}$. before and $11.6 \mathrm{~cm}$. after the dose in the case of the decholin sodium.

The blood N.P.N. was also unchanged by the decholin sodium, average $38.4 \mathrm{mgm}$. before and $39.4 \mathrm{mgm}$. after the 4 doses in 19 cases, and none 


\section{TABLE III}

Summary of results in comparison of diuretic effects of decholin and mercupurin

1. Average loss of weight in the 15-hour period (control)

2. Average diuretic effect of 2 grams decholin sodium in percentage of that of mercupurin ( 1 or $2 \mathrm{ml}$.)

3. Average increase in diuretic effect of mercupurin ( 1 or $2 \mathrm{ml}$.) by simultaneous injection of 2 grams decholin sodium

4. Increase in diuresis produced by raising dose of mercupurin from 1 to $2 \mathrm{ml}$. in one series of patients

5. Diuretic effect of 2 grams decholin sodium in percentage of effect of a $1 \mathrm{ml}$. dose of mercupurin in above series of patients

6. Diuretic effect of $\mathbf{2}$ grams decholin sodium in percentage of effect of the mercupurin in patients requiring

(a) $1 \mathrm{ml}$. mercupurin for about a $5 \mathrm{lb}$. diuresis (sensitive)

(b) $2 \mathrm{ml}$. mercupurin for about a $5 \mathrm{lb}$. diuresis (tolerant)

0.4 lbs.

30 per cent

26 per cent

37 per cent

33 per cent

36 per cent

17 per cent

of the individual cases showed any significant changes. There were no significant changes in the urine. There were no significant changes in the blood pressure. All patients experienced the bitter taste after the injection. One patient vomited. In one case, $8 \mathrm{ml}$. of the solution of decholin sodium was injected into the perivascular tissues. It caused mild fleeting pain which subsided without inflammation or thrombosis.

\section{SUMMARY AND CONCLUSIONS}

1. The effect of decholin sodium by intravenous injection in a dose of 2 grams was compared with that of mercupurin in a group of ambulatory patients with advanced heart disease and congestive failure.

2. This dose of decholin sodium causes a moderate diuretic effect in about 80 per cent of the cases, amounting on the average to about onethird as much as that of mercupurin.

3. When the decholin is given with mercupurin, the diuresis represents the summation of the effect of the two agents.

4. Patients resistant to the diuretic action of mercupurin are likely to be resistant to that of decholin as well.

5. The 2 gram dose of decholin sodium given together with the $1 \mathrm{ml}$. of mercupurin may be expected to produce a diuretic effect similar to doubling the dose of mercupurin.

6. The diuretic action of decholin sodium seems to be applicable to the same type of cases for which the organic mercurials are employed.

The authors are indebted to Drs. Paul Auspitz and Herbert Berger for assistance in this study.

\section{BIBLIOGRAPHY}

1. Modell, W., The optimal dose of mercurial diuretics. Ann. Int. Med., 1944, 20, 265.

2. Neubauer, E., Dehydrocholsäure, Ein wirksames, praktisch Ungiftiges Glied der Gallensäuregruppe. Klin. Wchnschr., 1923, 2, 1065.

3. Rahmlow, H., and Ritterband, H., Zur Dehydrocholsäure-Diurese. Deutsche med. Wchnschr., 1926, 52, 1992.

4. Adlersberg, D., and Taubenhaus, M., Blutdruck, Blutcholesterin und Diurese nach Zufuhr von Gallensäuren. Biochem. Ztschr., 1926, 177, 400.

5. Ruskin, A., and Herrmann, G. R., Studies in combined diuretic therapy. J. Lab. and Clin. Med., 1944, 29, 486.

6. Semler, R., Zur diuretischen Wirkung der Gallensäuren.' Med. Klin., 1926, 22, 891.

7. Kauftheil, L., and Neubauer, E., Uber Natriumdehydrocholatdiurese. Arch. f. exper. Path. u. Pharmakol., 1932, 166, 675.

8. Bix, H., Beitrag zur Diuresetherapie. Wien. klin. Wchnschr., 1928, 41, 1080.

9. Weigand, F. A., Diuretic action of intravenous sodium dehydrocholate. J. A. M. A., 1935, 105, 2034.

10. Bix, H., Decholin als Diuretikum. Wien. klin. Wchnschr., 1927, 40, 321.

11. Lebermann, F., Ueber die diuretische Wirkung der Gallensäuren. Deutsche med. Wchnschr., 1927, 53, 2020.

12. Adlersberg, D., Zur Rolle der Leber im Wasserhaushalt. Wien. Arch. f. inn. Med., 1934, 25, 401.

13. Stewart, H. L., and Cantarow, A., Renal lesions following injection of sodium dehydrocholate in animals with and without biliary stasis. Arch. Path., 1935, 20, 866.

14. Bachmann, R., Ueber die Wirkung des dehydrocholsauren Natriums (Decholin) auf die Niere der Katze. Virchow's Arch. f. path. Anat. u. Physiol., 1937, 299, 70.

15. Marengo, G., and Massimello, F., Der Einfluss der Tachidrolo-Decholin-Mischspritze auf die Bilirubinämie und die Diurese. Arch. f. exper. Path. u. Pharmakol., 1935, 178, 486. 